\title{
The Avian Transcription Factor c-Rel Is Expressed in Lymphocyte Precursor Cells and Antigen-Presenting Cells During Thymus Development
}

\author{
C. HUGUET ${ }^{\text {a }}$, F. BOUALI ${ }^{a}$, P.J. ENRIETTO ${ }^{\text {b }}$, D. STEHELIN ${ }^{a}$, B. VANDENBUNDER ${ }^{a}$ and C. ABBADIE ${ }^{a}$ \\ ${ }^{a}$ Laboratoire d'Oncologie Moléculaire, URA1160, Institut de Biologie de Lille, 1 rue Calmette, 59019 Lille Cedex, France; ${ }^{\mathrm{b}}$ Department \\ of Microbiology, State University of New York at Stony Brook, New York 11794
}

(Received 6 January 1997; Revised 5 June 1997; In final form 18 June 1997)

\begin{abstract}
Transcription factors of the Rel/NF- $\kappa \mathrm{B}$ family are widely involved in the immune system. In this study, we investigate the in vivo expression of the avian protein c-Rel in the T-cell lineage during thymus development. The majority of thymocytes do not express the c-Rel protein. However, lymphocyte precursor cells that colonize the thymus express the $\mathrm{c}$-Rel protein shortly after their homing in the organ and before they begin to differentiate. c-Rel is also detected in different subsets of antigen-presenting cells such as epithelial cells, dendritic cells, and macrophages. In vitro studies have shown that Rel/NF- $\kappa \mathrm{B}$ proteins are sequestered in an inactive form in the cytoplasm by interaction with the $\mathrm{I} \kappa \mathrm{B} \alpha$ inhibitory protein. By immunocytochemistry, we show that in vivo c-Rel is localized in the cytoplasm of antigen-presenting cells but in both the cytoplasm and nucleus of lymphocyte precursor cells. The cytoplasmic localization of c-Rel in antigen-presenting cells correlates with a high expression of $\mathrm{I} \kappa \mathrm{B} \alpha$, whereas the nuclear localization of c-Rel in lymphocyte precursor cells correlates with a much lower expression of $\mathrm{I} \kappa \mathrm{B} \alpha$. These results suggest that c-Rel might be constitutively activated in lymphocyte precursor cells.
\end{abstract}

Keywords: Rel/NF- $\kappa \mathrm{B}$, thymus, lymphocyte precursor cells, antigen-presenting cells, avian development

\section{INTRODUCTION}

The proto-oncogene c-rel encodes a transcription factor of the Rel/NF- $\kappa \mathrm{B}$ family. The members of this family share a highly conserved 300 amino acid Nterminal domain, the Rel Homology Domain (RHD), involved in DNA binding, dimerization, nuclear localization, and interaction with inhibitory proteins of the $\mathrm{I} \kappa \mathrm{B}$ family. Rel/NF- $\kappa \mathrm{B}$ proteins associate as homo- or heterodimers and bind a specific DNA sequence, the $\kappa \mathrm{B}$ motif, in the promoter of their target genes. Inside the Rel/NF- $\kappa \mathrm{B}$ family, two subfamilies of proteins can be defined based on the function of their C-terminal domains. The first one includes cRel, RelA, RelB, Dorsal, and Dif, which contain a transactivating domain in their $\mathrm{C}$ terminus. The

\footnotetext{
${ }^{*}$ Corresponding author.
} 
second family is composed of the precursor proteins NF- $\kappa \mathrm{B} 1$ and NF- $\kappa \mathrm{B} 2$, which contain I $\kappa \mathrm{B}$-like ankyrin repeats in their $\mathrm{C}$ terminus. NF- $\kappa \mathrm{B} 1$ and NF- $\kappa \mathrm{B} 2$ undergo a proteolytical processing that eliminates their ankyrin motifs and generates proteins p50 and $\mathrm{p} 52$, respectively. These mature p50 and p52 are able to homo- or heterodimerize with other members of the $\mathrm{Rel} / \mathrm{NF}-\kappa \mathrm{B}$ family, thus becoming active transcription factors (reviewed in Miyamoto and Verma, 1995; Verma et al., 1995).

In most cell types, Rel/NF- $\kappa \mathrm{B}$ dimers are found in an inactive form sequestered in the cytoplasm by an ankyrin repeat protein of the $\mathrm{I} \kappa \mathrm{B}$ family. The $\mathrm{I} \kappa \mathrm{B}$ family is composed of $\mathrm{I} \kappa \mathrm{B} \alpha, \mathrm{I} \kappa \mathrm{B} \beta$, and $\mathrm{Bcl} 3$, as well as NF- $\kappa \mathrm{B} 1$ and NF- $\kappa \mathrm{B} 2$ precusors in their unprocessed form. The activation of the Rel/NF- $\kappa \mathrm{B}$ proteins is regulated by a posttranslational mechanism, which includes the phosphorylation of the $\mathrm{I} \kappa \mathrm{B}$ inhibitor and its subsequent degradation, thus liberating the Rel/NF- $\kappa \mathrm{B}$ dimer, which can translocate into the nucleus (reviewed in Verma et al., 1995; Miyamoto and Verma, 1995). The inhibitor degradation occurs within minutes after stimulation, making the $\mathrm{Rel} / \mathrm{NF}-\kappa \mathrm{B}$ transcription factors very efficient when rapid responses are ne'eded. The immune system takes advantage of this property and extensively uses the Rel/NF- $\kappa \mathrm{B}$ proteins for regulating cytokine, growth factor, acute phase protein, and immunoreceptor gene expression (review in Bauerle and Henkel, 1994; Kopp and Ghosh, 1995). The Rel/NF- $\kappa$ B proteins are also involved in pathogenesis of the immune system. In humans, alterations at the rel locus have been found in follicular and diffuse large cell lymphomas (Lu et al., 1991) and amplifications of the c-rel gene have been detected in primary mediastinal thymic Bcell lymphoma (Joos et al., 1996) and in extranodal diffuse large cell lymphoma (Houldsworth et al., 1996).

The expression of c-Rel has been widely described in the hematopoietic organs during mouse development. In the fetal liver, the c-Rel protein expression is restricted to hematopoietic precursor cells of the erythroid and B-cell lineage. In the spleen, c-Rel expression is also found in B cells. In the embryonic thymus, c-Rel is essentially detected in medullary epithelial cells and in some B cells, whereas thymocytes do not express any c-Rel protein. In the T-cell lineage, only mature helper and cytotoxic $\mathrm{T}$ cells of the lymph nodes express c-Rel (Carrasco et al., 1994). A better understanding of the mouse c-Rel functions in hematopoiesis and immune system was obtained with the establishment of null mice (Köntgen et al., 1995). In these mice, no developmental defect in any hematopoietic lineage could be evidenced, indicating that c-Rel is not essential for embryonic hematopoiesis. However, c-rel-deficient mice displayed defects in humoral immunity and unresponsiveness of mature $\mathrm{B}$ and $\mathrm{T}$ cells to most mitogenic stimuli.

In the avian embryo, such exhaustive studies have not yet been performed. Nevertheless previous in vitro analysis suggested a potential involvement of some Rel/NF- $\kappa \mathrm{B}$ members in avian hematopoiesis (reviewed in Huguet et al., 1994). Northern blot analysis revealed that c-rel is predominantly expressed in chick hematopoietic organs such as the bursa of Fabricius, the thymus, the spleen, and the bone marrow (Moore and Bose, 1989). Moreover, the avian retrovirus Rev-T, bearing the v-Rel oncogene, causes fatal lymphomatosis in chicken (Sevoian et al., 1964; Olson, 1967). The in vivo preferential target cells for Rev-T are immature and mature lymphoid cells expressing B- and T-cell determinants as well as myeloid cells (Lewis et al., 1981; Barth et al., 1990; Zhang et al., 1991). In vitro studies also showed that the majority of v-Rel transformed hematopoietic cells bore lymphoid markers (Morrison et al., 1991). More recently, a v-RelER fusion protein has been shown to transform an early progenitor of dendritic and neutrophil cells (Boehmelt et al., 1995).

Altogether, these results prompted us to further investigate the relationships between c-Rel and hematopoiesis in chicken. We focused our study on the embryonic thymus that constitutes the primary site of T-cell development. Since the activity of the avian c$\mathrm{Rel}$ is tightly dependent on interactions with the $\mathrm{I} \kappa \mathrm{B} \alpha$ inhibitor (Morrison et al., 1989; Davis et al., 1990; Kerr et al., 1991; Kochel et al., 1991; Hrdlickova et al., 1995; Schatzle et al., 1995), we studied in parallel the expression of both genes and searched for the 
nucleocytoplasmic localization of the c-Rel protein, which gives evidence about its activation.

\section{RESULTS}

\section{High Expression of c-rel in the Thymus Correlates with the Differentiation of the Medulla}

The analysis of c-rel expression was performed at three stages representative of the avian thymus development: (1) at E9.5, the thymus is an epitheliomesenchymal rudiment filled up with very immature precursor cells; (2) at E15, small medullary areas are separating from the cortex, figuring the maturation of the thymic stroma; (3) at E19, the avian thymic structure is almost completed with well-defined cortical lobules and large medullary areas. The cortex is essentially composed of double-positive $\mathrm{CD} 4^{+} \mathrm{CD}^{+}$immature thymocytes enclosed in an epithelial meshwork, whereas the medulla is mainly composed of single-positive mature thymocytes among antigen-presenting cells and epithelial cells.

In situ hybridization experiments performed at E9.5 show that c-rel mRNAs are homogeneously expressed throughout the thymic organ [Figures 1(A) and 1(B)]. At E15, c-rel expression becomes heterogeneous with higher levels in the developing medulla than in the cortex [Figures 1(C) and 1(D)]. At E19, this heterogeneous distribution of c-rel mRNAs is even more accentuated [Figures 1(E) and 1(F)]. At both E15 and E19 stages, high magnifications show that inside the medulla the areas of highest expression correspond to cells with large cytoplasm and nucleus that could be clusters of dendritic or epithelial cells and macrophages, according to their morphology and localization. In contrast, cortical and medullary thymocytes, recognizable by a small round nucleus and a low cytoplasmic volume, express lower levels of c-rel mRNAs (Figure 2). Thus, during the thymus development, the high expression of c-rel correlates with the establishment of mature medullary areas, whereas the expression in developing thymocytes is continuous and at low levels.
The c-Rel Protein Is Expressed in Endothelial, Epithelial, and Antigen-Presenting Cells of the Thymus

To investigate the c-rel expression at the protein level, Western blot experiments were performed with an immuno-purified anti-c-Rel antibody on hematopoietic organs at different developmental stages. One major band at $68 \mathrm{kD}$, corresponding to the avian c-Rel protein molecular mass (Simek and Rice, 1988), is detected in the thymus at E15 and E19, although less intensely than in the spleen and the bursa of Fabricius (Figure 3). Immunocytochemistry experiments were performed with this same anti-c-Rel antibody on serial thymus sections to identify the c-Rel-expressing cells. At E15 and E19, consistent with its mRNA distribution, the c-Rel protein is predominantly expressed inside the medulla in large clusters of cells (Figure 4). Some isolated cells scattered in the cortex also express c-Rel. Cortical as well as medullary thymocytes, identified with anti-CD3,-CD4, and -CD8 antibodies (data not shown), do not express any detectable amounts of c-Rel. At least four different types of cells were found to express c-Rel. The most easily identifiable are endothelial cells bordering the thymic vessels [Figure 5(A)]. Epithelial cells of different morphology and localization, identified with an anti-cytokeratin antibody (data not shown), also express c-Rel: Some line the cortical lobules [Figure 5(B)] and others form large clusters inside the central medulla [Figure 5(C)]. Other medullary clusters, containing two to three large cells with large vacuoles, also express c-Rel. In these cells, the protein is clearly localized in the cytoplasm [Figure 5(D)]. These cells displayed the violet color characteristic of myeloid cells when stained by the panoptic method of Pappenheim (data not shown). According to their morphology, localization and staining properties, they could be dendritic cells. At the corticomedullary junction, inside the medulla and scattered inside the cortex, isolated large round cells also express c-Rel in their cytoplasm [Figure 5(E)]. These cells possess a characteristic eccentric nucleus that is clearly negative. We assume that these cells are macrophages because of their morphology, pink staining by the 

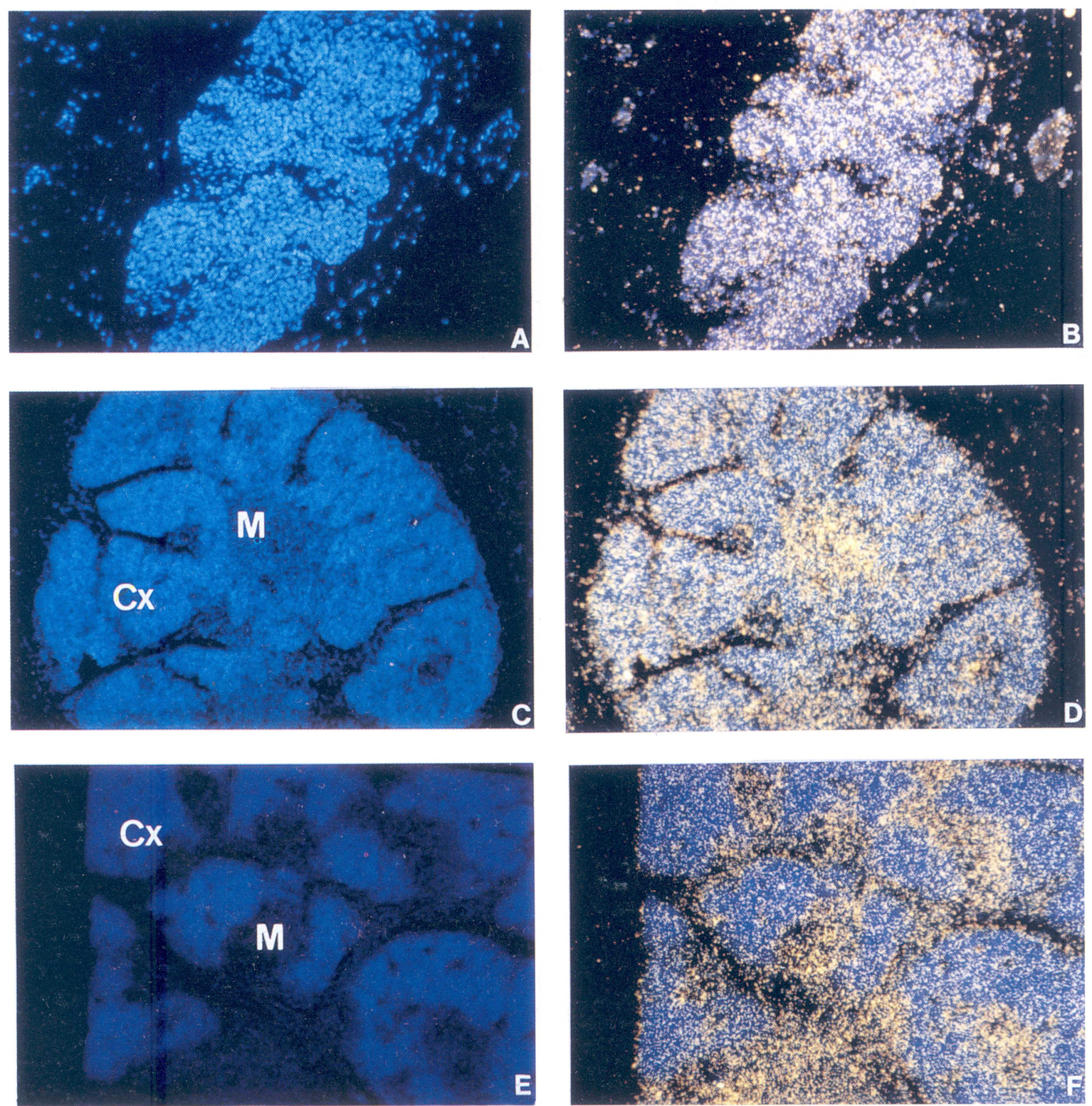

Figure 1 (See Color Plate at back of issue.) In situ hybridization analysis of c-rel expression pattern in E9.5, E15, and E19 thymuses. In order to visualize the nuclei, sections were counterstained with the DNA intercalant Hoechst 33258, which fluoresces in blue under UV illumination. Sections were observed under UV illumination alone (A, C, and E) or UV and dark field illumination (B, D, and F). (A and B) At E9.5, c-rel is homogeneously expressed. (C and D) At E15, c-rel expression becomes heterogeneous with higher expression in the medulla (M) than in the cortex (Cx). (E and F) At E19, the heterogenous expression of c-rel is even more obvious with the highest levels in the medulla. Magnification: $\times 100$. 
Pappenheim method (data not shown), and because some of them, probably the most mature, display a nonspecific esterase activity detectable in situ characteristic of the monocytic lineage (Duncan and McArthur, 1978) (data not shown).

The c-rel expression in dendritic cells and macrophages was further characterized in primary cell culture. These cells were isolated from E19 thymuses by fractionation on a bovine serum albumin gradient and cultured on the basis of their glass-adherence properties (Oliver and Le Douarin, 1984). In culture, dendritic cells appear as long bipolar cells with the nucleus at one pole and large vacuoles. The c-Rel protein is clearly observed in the cytoplasm, whereas there is no detectable protein in the nucleus [Figure 5(F)]. Macrophages appear as large round cells with an eccentric nucleus. In these cells, c-Rel is also restricted to the cytoplasm [Figure 5(G)].
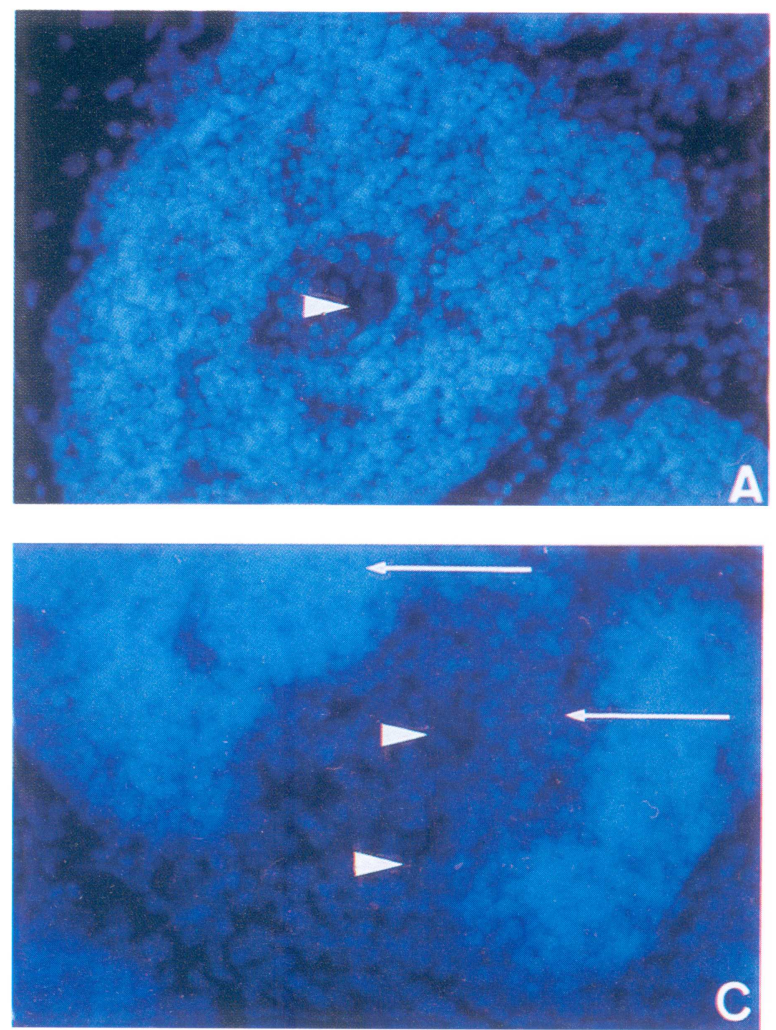

\section{Lymphocyte Precursor Cells Express the c-Rel Protein Both in Their Cytoplasm and Nucleus}

In the cortex at E19, a few round cells, larger than most of the cortical thymocytes, also express c-Rel. They are usually located in the marginal cortex and often observable in only one lobule [Figure 6(A)]. Unlike the majority of cortical thymocytes, numerous cells of the marginal cortex do not express any of the $\mathrm{CD} 3, \mathrm{CD} 4$, or $\mathrm{CD} 8$ cell-surface markers (data not shown), indicating that they are very immature (Dieterlen-Lièvre, 1994). Moreover, the Pappenheim coloration reveals that the large round cells of the marginal cortex are stained in dark blue compared to more mature thymocytes that appear pale blue [Figure 6(C)]. This dark blue staining indicates that they are highly basophilic, a characteristic of lymphocyte precursor cells (LPCs). Therefore, to further identify
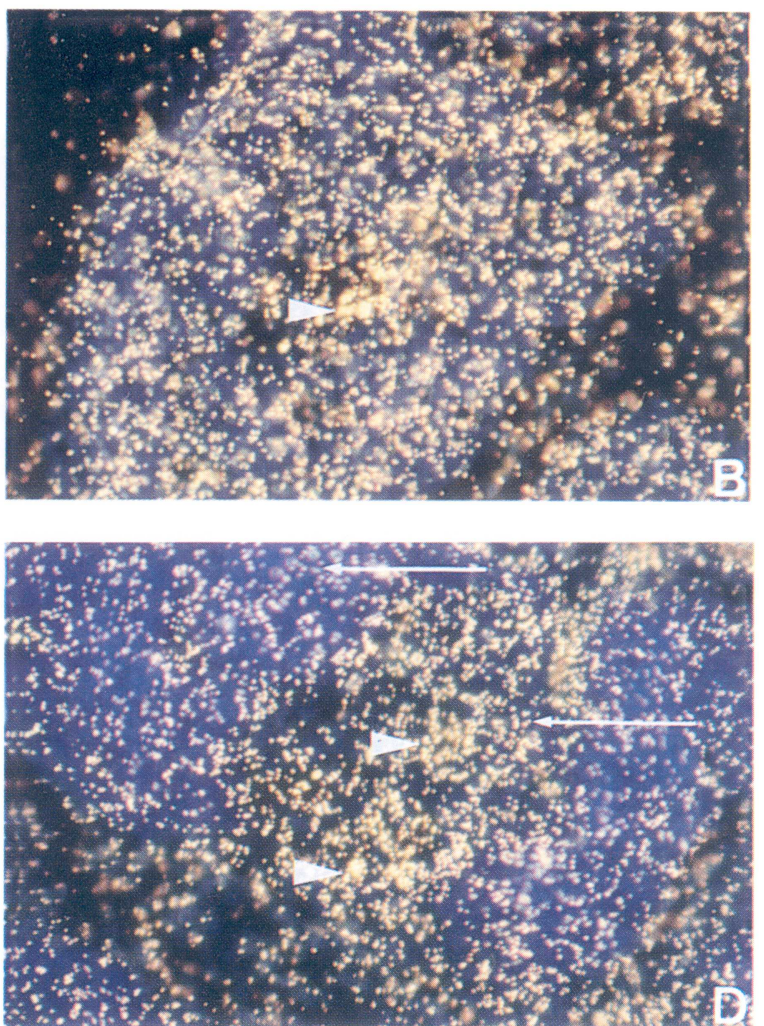

Figure 2 (See Color Plate at back of issue.) Higher magnification of c-rel expression in the medulla of E15 and E19 thymuses. (A and C) Hoechst staining. (B and D) In situ hybridization. At both stages E15 and E19, the highest expressions are found inside the medulla in clusters of large cells with large nuclei appearing as dark areas (arrowheads). Cortical and medullary thymocytes express low levels of c-rel (arrows). Magnification: $\times 300$. 


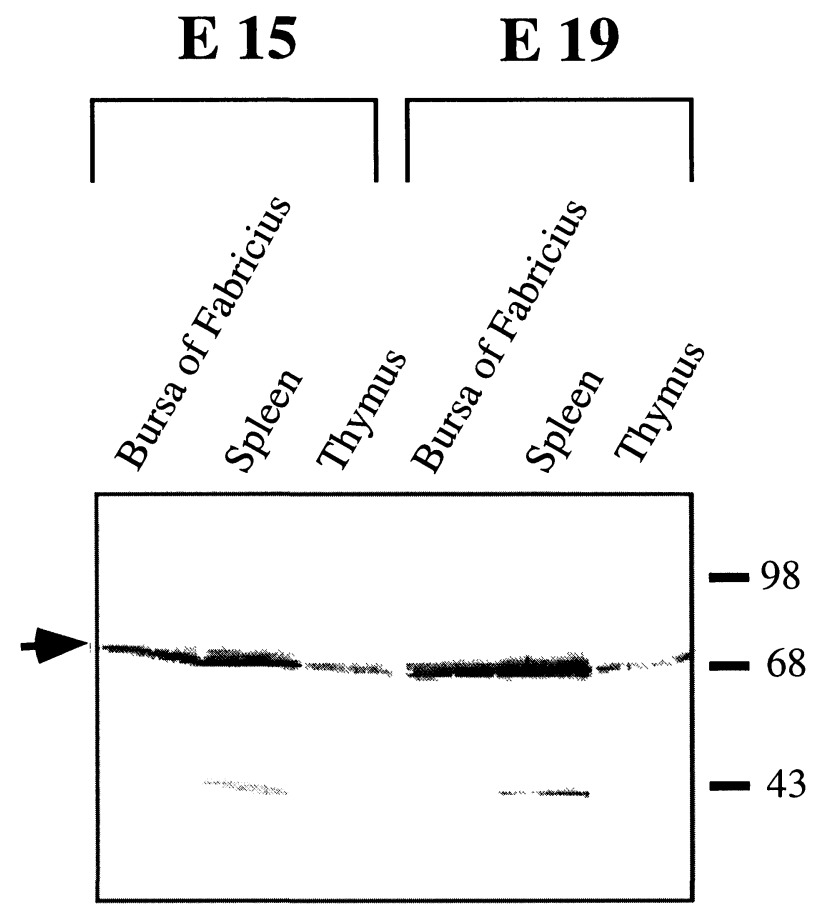

FIGURE 3 Western blot of protein extracts of E15 and E19 hematopoietic organs. The p68 $8^{\text {crel }}$ protein is indicated by an arrow. The lower band seen in spleen extracts was shown to be a breakdown product (data not shown).
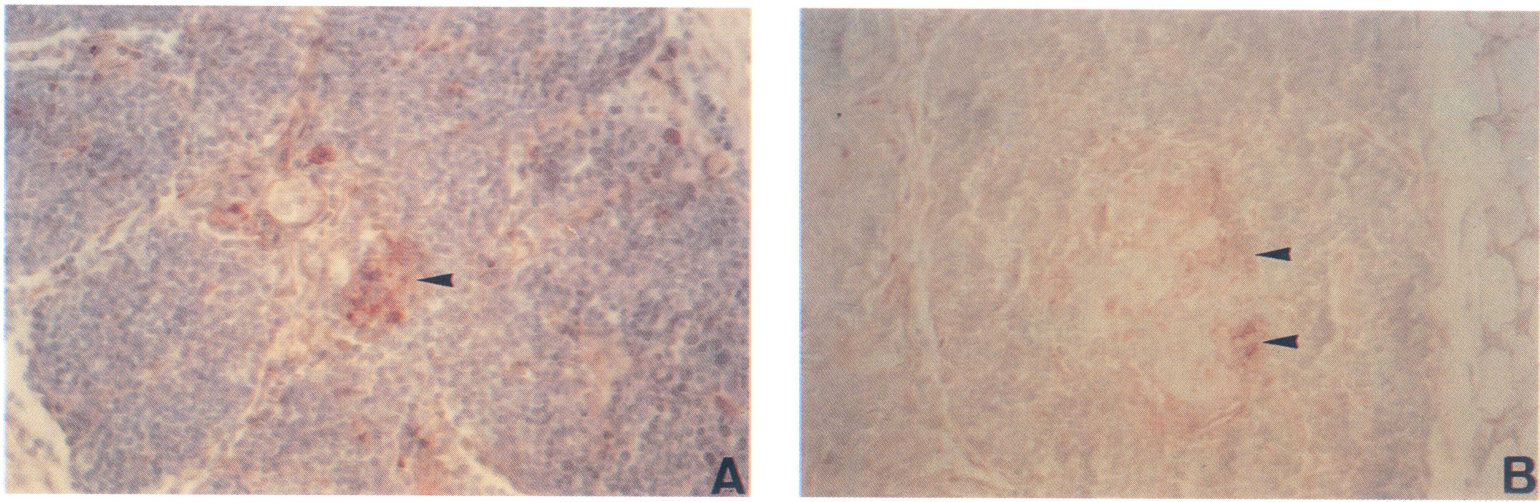

Figure 4 (See Color Plate at back of issue.) Immunocytochemical detection of c-Rel in E15 and E19 thymuses. Cells expressing c-Rel are stained in red in contrast to negative cells, which appear in blue due to hematoxylin counterstaining. At both stages (A) E15 and (B) E19, c-Rel is predominantly expressed in cell clusters in the medullary areas (arrowheads). Magnification: $\times 200$. 

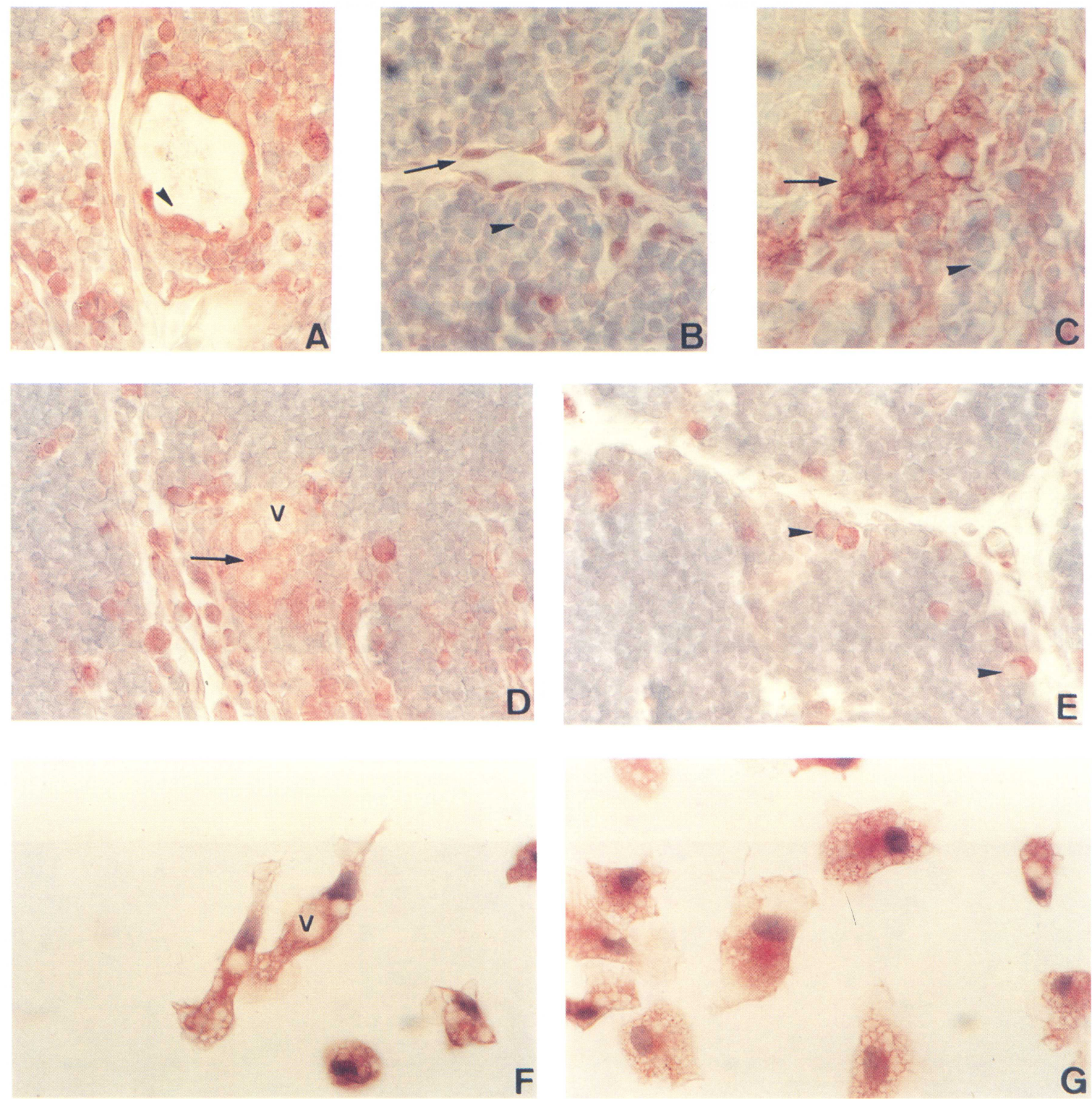

Figure 5 (See Color Plate at back of issue.) High magnification of the immunocytochemical detection of c-Rel in E19 thymus and in primary cell culture. (A) c-Rel is detected in endothelial cells (arrowhead). (B) Epithelial cells lining the cortical lobules express c-Rel (arrow), whereas cortical thymocytes are clearly negative (arrowhead). (C) c-Rel is also detected in clusters of medullary epithelial cells (arrow); medullary thymocytes are negative (arrowhead). (D) Clusters of dendritic cells with vacuoles (V) express c-Rel in their cytoplasm (arrow). (E) Isolated macrophages with an eccentric nucleus also express c-Rel in their cytoplasm (arrowheads). (F and G) Detection of c-Rel in primary culture of dendritic cells and macrophages: (F) long bipolar dendrictic cells with large vacuoles (V) and (G) macrophages with an eccentric nucleus express c-Rel in their cytoplasm. In both type of cells, the nuclei are clearly negative and appear stained in blue by the hematoxylin. Magnification: $\times 550$. 
these cells, we investigated the expression of c-Rel during the first wave of thymus colonization by LPCs.

The thymus rudiment is colonized by three consecutive waves of LPCs: from E6.5 to E8, from E12
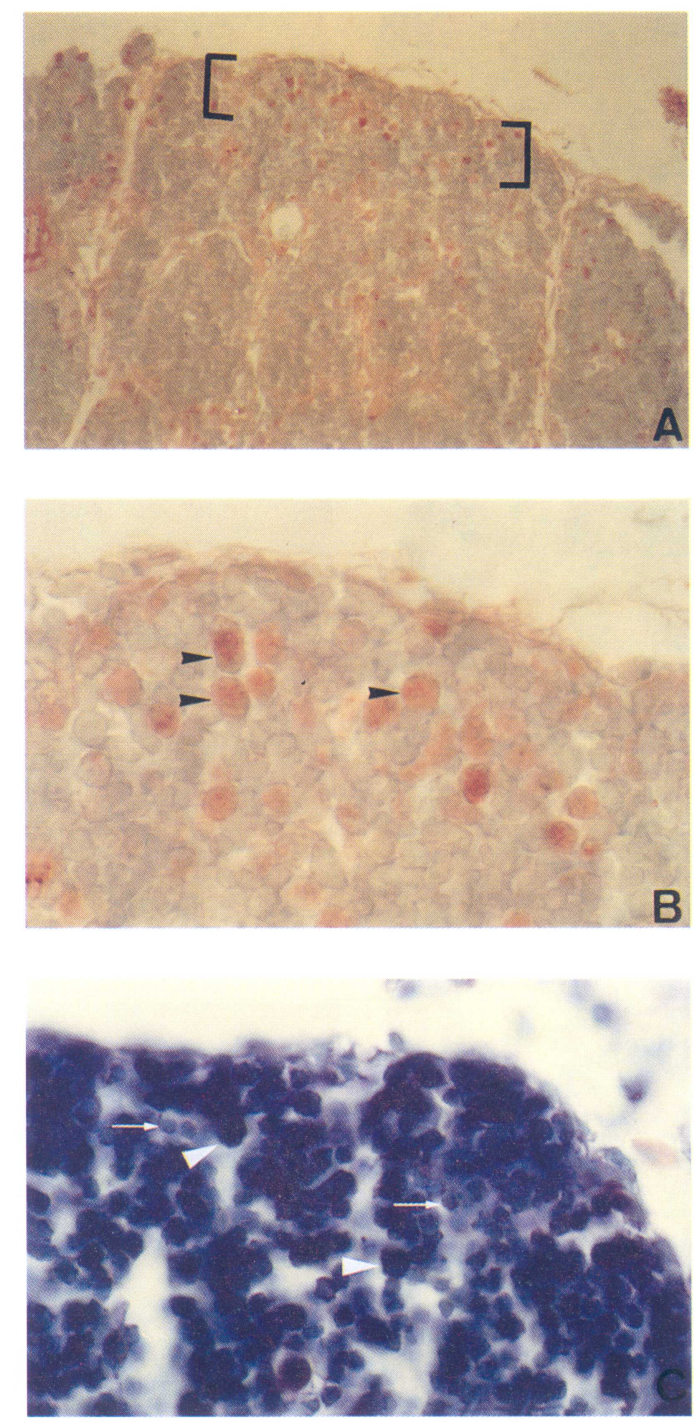

Figure 6 (See Color Plate at back of issue.) Immunocytochemical detection of c-Rel in lymphocyte precursor cells (LPCs) in E19 thymus. (A). In the marginal cortex (brackets), some LPCs express c-Rel. (B) High magnification showing that c-Rel is localized in the nucleus and cytoplasm of these cells (arrowheads). (C) LPCs are stained in dark blue by the Pappenheim coloration (arrowheads) compared to small cortical thymocytes that are pale blue (arrows). Magnification: $\times 200$ in (A) and $\times 750$ in (B) and (C). to E14, and from E18 to hatching. The first wave of LPCs gives rise to the myeloid and lymphoid cells of the thymus; they are renewed in the successive waves of colonization. Between the three colonization periods, the thymus is refractory to the entry of precursor cells (Coltey et al., 1987). To estimate the number and localization of LPCs in thymus sections, we used the panoptic Pappenheim coloration. At E8.5, just after the first wave of colonization, round dark blue cells are detected [Figure 7(A)]. Comparison with sections treated with the anti-c-Rel antibody indicates that no cells express c-Rel at this stage [Figure 7(B)]. At E9.5, the thymus is filled up with dark blue stained LPCs. the majority of these cells express high levels of c-Rel [Figures 7(C) and 7(D)]. At E11, nearly no large round cells stained in dark blue are detected; the majority of round cells are small and stained in pale blue, indicating that they are already differentiated thymocytes [Figure 7(E)]. These cells do not express c-Rel [Figure 7(F)]. Thus, c-Rel is expressed in LPCs during a limited period between the homing and the beginning of the differentiation. Observation at high magnification of sections at E9.5 and E19 reveals that c-Rel is localized in both the cytoplasm and nucleus of LPCs [Figures 6(B) and 7(D)].

\section{Nuclear or Cytoplasmic Localization of c-Rel Correlates Respectively with Low and High Levels of $i k b a$ Gene Expression}

Since the nucleocytoplasmic localization of c-Rel in antigen-presenting cells and lymphocyte precursor cells differs, we investigated the expression of $i k b a$, the gene that encodes $\mathrm{I} \kappa \mathrm{B} \alpha$, in these cells at $\mathrm{E} 9.5$ and E19.

At E19, the ikba gene shows high levels of expression in the medulla, whereas weaker signals are found in the cortex [Figures 8(A) and 8(B)]. Within the medulla, intense signals are detected in clusters of large cells with large nucleus as well as in thymocytes [Figures $8(\mathrm{C})$ and $8(\mathrm{D})$ ]. The expression of $i k b a$ is also detected in round isolated macrophages located at the cortico-medullary junction and in the interlobular spaces (data not shown). The expression in macrophages and dendritic cells was confirmed by in 
situ hybridization on primary cell cultures [Figure 8(E)]. Additionally, ikba is highly expressed in endothelial cells [Figures $8(\mathrm{~F})$ and $8(\mathrm{G})$ ] and in epithelial cells lining the cortex [Figures $8(\mathrm{H})$ and
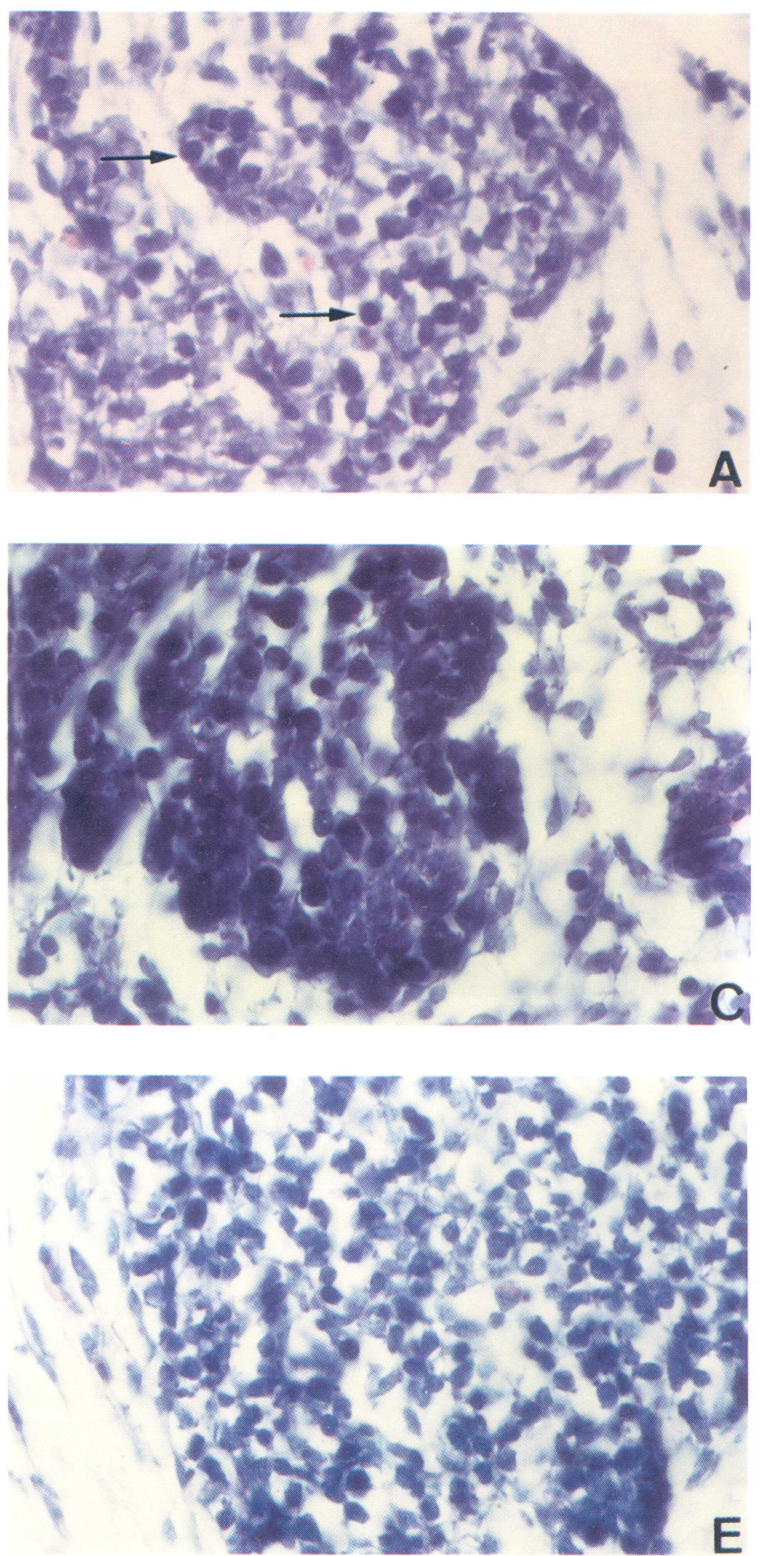

8(I)]. At E9.5, the $i k b a$ expression is heterogeneous. It is highly expressed in a few isolated cells, probably corresponding to the first differentiating antigenpresenting cells, while it is expressed at low levels in
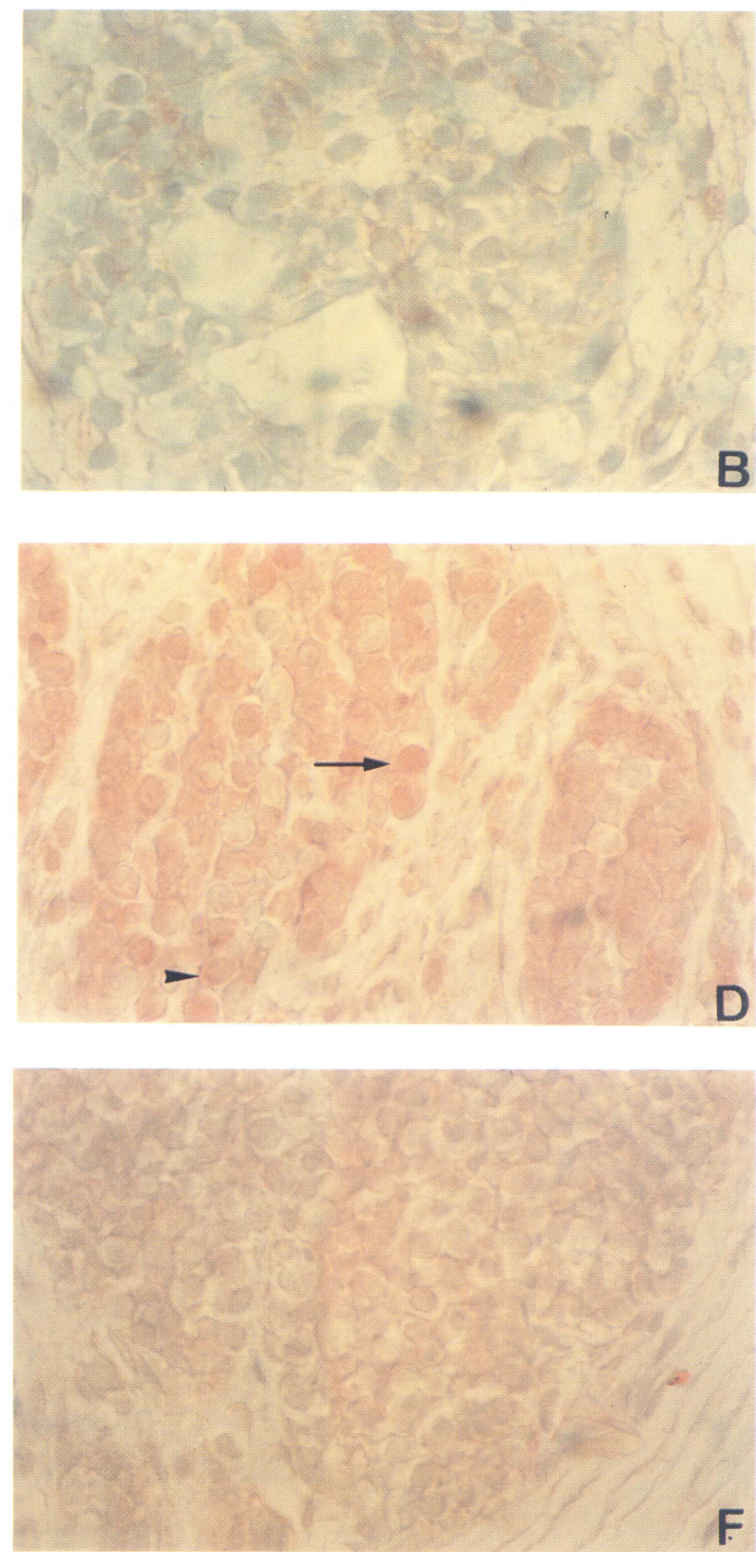

Figure 7 (See Color Plate at back of issue.) Immunocytochemical detection of c-Rel in LPCs during the first wave of colonization. Pappenheim coloration (A, C, E) and immunocytochemistry (B, D, F). At E8.5: (A) a few large round LPCs are stained dark blue by the Pappenheim coloration (arrows); (B) c-Rel is not detected in these cells. At E9.5: (C) the thymus is filled up with dark blue stained LPCs; (D) the majority of these cells express c-Rel and the protein is detected in the cytoplasm (arrowhead) or both in the nucleus and cytoplasm (arrows). At E11: (E) the thymus mainly contains differentiating thymocytes that are small cells stained in pale blue; (F) they do not express c-Rel. Magnification: $\times 550$. 

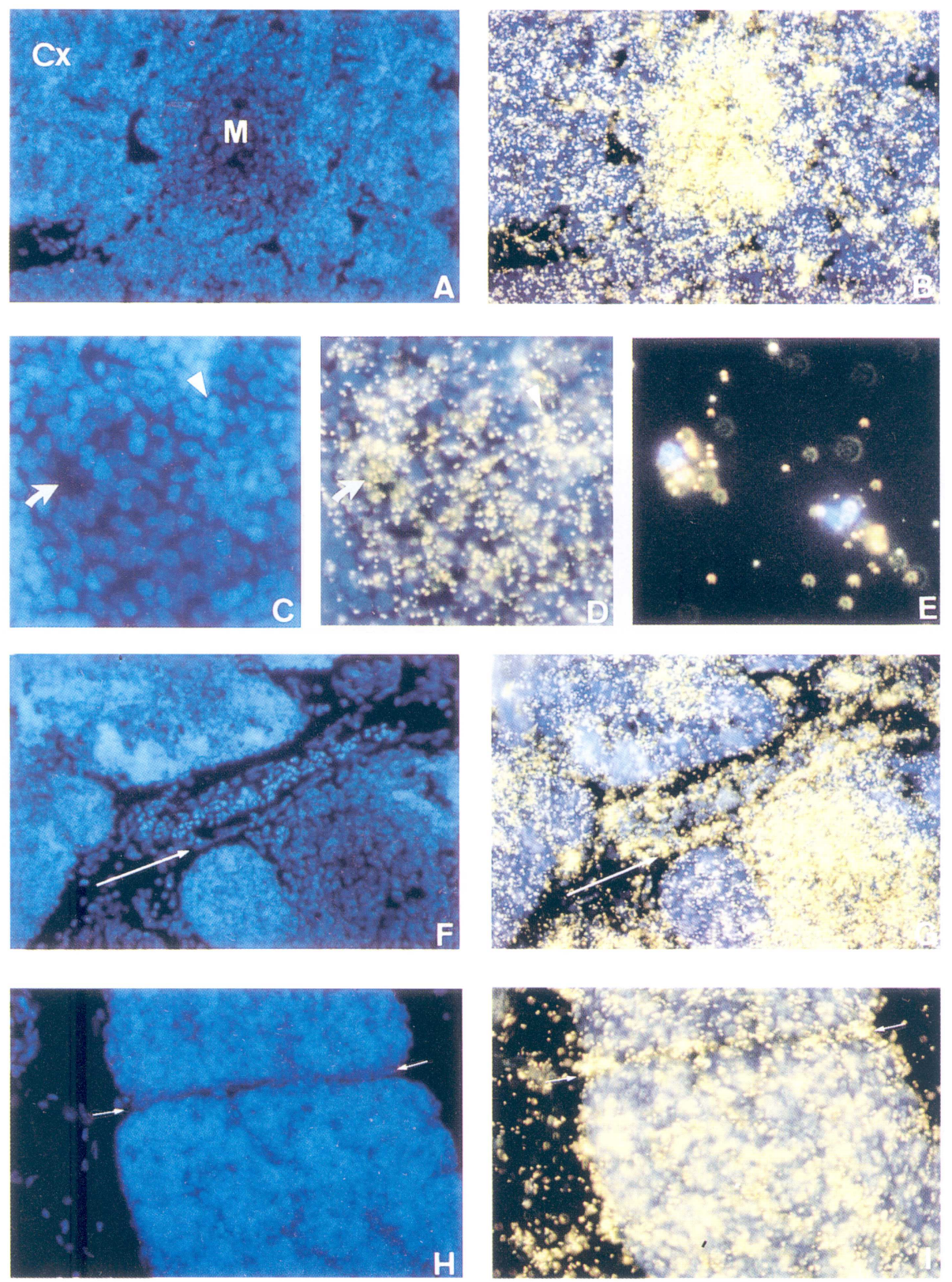

Figure 8 (See Color Plate at back of issue.) In situ hybridization analysis of $i k b a$ expression in E19 thymus and primary cell culture. (A, C, F, and H) Hoechst staining. (B, D, E, G, and I) In situ hybridization. (A and B) At E19, ikba is highly expressed in the medulla (M). (C and D) Higher magnification of the medulla shows $i k b a$ expression in clusters of large cells appearing as dark areas (arrows) and in medullary thymocytes (arrowheads). (E) $i k b a$ expression in primary culture of macrophages and dendritic cells. (F and $\mathrm{G}) i k b a$ is also expressed in endothelial cells (arrow) and (H and I) in epithelial cells lining the cortical lobules (arrows). Magnification: $\times 200$ in (A) and (B), $\times 550$ in $(\mathrm{C}$ to $\mathrm{E}), \times 300$ in (F to I). 
the majority of lymphocyte precursor cells (Figure 9). In summary, ikba expression is high in all of the stromal cells, where c-Rel protein is cytoplasmic. In contrast, low levels of $i k b a$ are detected in LPCs, where c-Rel is detected in both the cytoplasm and nucleus.

\section{DISCUSSION}

Previous studies have shown that the mouse protooncogene c-rel is involved in mature T-cell activation and in T-cell education via an indirect role in thymic epithelial cells (Carrasco et al., 1994; Köntgen et al., 1995). In this study, we investigated the expression of the avian proto-oncogene c-rel and its $\mathrm{I} \kappa \mathrm{B} \alpha$ inhibitor during the $\mathrm{T}$-cell development occuring in the chick embryonic thymus.

\section{c-Rel Is Expressed in the Nucleus of Proliferating Lymphocyte Precursor Cells}

Immunocytochemistry experiments pointed out the expression of c-Rel in a specific subset of T cells, the lymphocyte precursor cells (LPCs), where it had never been detected so far. Colonization of the avian thymus by LPCs has been widely studied through the construction of quail-chick chimeras (Le Douarin and Jotereau, 1975; Coltey et al., 1987). The thymus

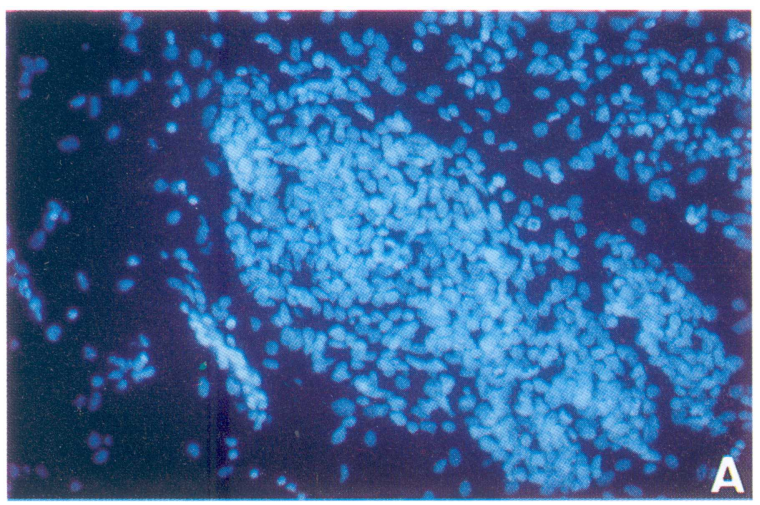

rudiment is seeded by three waves of LPCs from E6.5 to $\mathrm{E} 8$, from $\mathrm{E} 12$ to $\mathrm{E} 14$, and from E18 onwards. Between these three periods, the thymus is refractory to hematopoietic cell entry. LPCs of the second wave stay dormant about 3 days before starting proliferation (Jotereau and Le Douarin, 1982). Differentiation of LPCs gives birth to three T-cell sublineages. The first fully differentiated cells appear at E12; they express the TCR1/CD3 complex. Cells expressing the TCR2/CD3 complex appear at E14-15. The TCR3/ CD3 cells constitute the last T-cells to differentiate from E17 (reviewed in Dieterlen-Lièvre, 1994). At E8.5, after the end of the first wave of colonization, LPCs in the thymus rudiment do not express c-Rel. At E9.5, the number of LPCs in the thymus has greatly increased. Most of them express c-Rel. This expression is no longer detected at E11 when differentiation of the first T-cell sublineage begins. Thus, the expression of c-Rel in LPCs seems to occur during their proliferation and to be induced at E9.5. cRel-expressing LPCs were also observed at E19. At this stage, temporal correlations are more difficult to establish since the duration of the third wave of colonization is not well defined.

It is worth to notice that in LPCs, c-Rel is expressed both in the cytoplasm and nucleus. Therefore, c-Rel might be constitutively activated in proliferating LPCs and that way may sustain their proliferation. A constitutive activation of c-Rel has already been

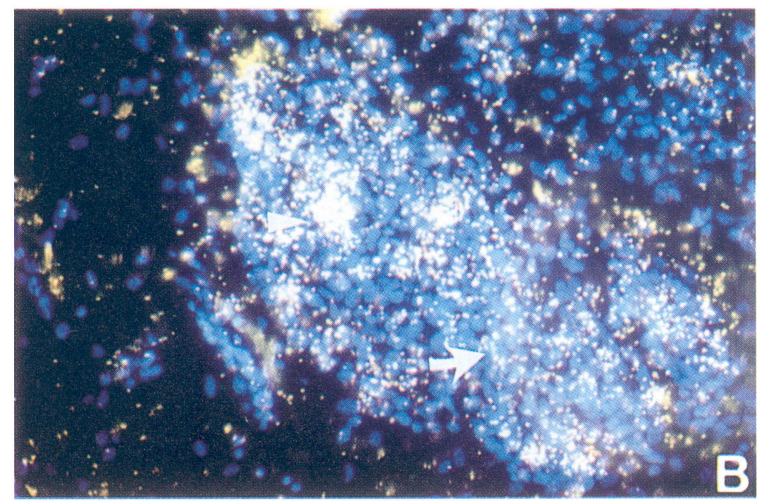

Figure 9 (See Color Plate at back of issue.) In situ hybridization analysis of $i k b a$ expression in E9.5 thymus. (A) Hoechst staining. (B) In situ hybridization. At E9.5, ikba is heterogeneously expressed throughout the organ. LPCs, which represent the majority of cells, only express low levels of $i k b a$ (arrows). High expressing cells (arrowheads) cannot be clearly identified. Magnification: $\times 200$. 
described in a mature mouse B-cell line and was explained by a high and continuous degradation of $\mathrm{I} \kappa \mathrm{B} \alpha$ in the absence of external signals (Miyamoto et al., 1994). Here, we show that avian LPCs express low levels of $\mathrm{I} \kappa \mathrm{B} \alpha$, suggesting that the constitutive nuclear localization of c-Rel might be due to a low expression of the inhibitor. This hypothesis requires further investigation of $\mathrm{I} \kappa \mathrm{B} \alpha$ expression at the protein level.

The involvement of c-Rel in proliferation has already been suggested by in vitro experiments showing that overexpression of c-Rel in chicken embryo fibroblasts led to morphological transformation, life-span extension, and proliferation (Abbadie et al., 1993; Kralova et al., 1994). The constitutive nuclear localization of c-Rel in LPCs documented in this paper represents the first in vivo argument in favor of a participation of this transcription factor in the proliferation of very immature progenitor of $\mathrm{T}$ cells.

\section{c-Rel Is Expressed in the Cytoplasm of Thymic Antigen-Presenting Cells}

In avian thymuses from E15 to E19, c-Rel is expressed in epithelial cells, dendritic cells, and macrophages. Avian thymic epithelial cells, dendritic cells, and macrophages share common surface antigens and particularly MHC molecules (Peck et al., 1982; Guillemot et al., 1984; Boyd et al., 1992); they constitute the three main types of antigen-presenting cells (APCs) of the thymus. These cells govern positive and negative selection of $\mathrm{T}$ cells in the thymus, via interactions between their MHC and the $\mathrm{T}$-cell receptor (TCR) (reviewed in von Boehmer, 1994; Nossal, 1994).

In vitro studies have shown that avian MHC class I and II genes are induced when c-Rel or v-Rel are overexpressed (Hrdlickova et al., 1994). Therefore, a potential function of c-Rel in APCs could be to regulate the expression of $\mathrm{MHC}$ genes. However, in macrophages, besides genes involved in T-cell maturation, c-Rel could regulate genes involved in basic antimicrobial functions, since in HD11 cells, a chicken myelomonocytic cell line, RelA, and c-Rel are able to activate the transcription of the lysozyme gene (Phi Van, 1996).

In vitro experiments have demonstrated that in chicken, $\mathrm{I} \kappa \mathrm{B} \alpha$ is able to inactivate $\mathrm{c}-\mathrm{Rel}$ by sequestering it in the cytoplasm (Davis et al., 1990; Kerr et al., 1991). In accordance with these studies, our in situ hybridization analysis revealed that in vivo, high expression of $i k b a$ is detected in all of the stromal cells that express the c-Rel protein in the cytoplasm, that is, in endothelial cells, epithelial cells, dendritic cells, and macrophages.

The expression pattern of c-Rel is more widespread in chick than in mouse APCs, where c-Rel appears restricted to medullary epithelial cells. Moreover, in mouse, the expression of c-Rel in progenitor cells is restricted to the erythroid and B-cell lineages (Carrasco et al., 1994). Our results on $i k b a$ are also different from those obtained in mouse. In the mouse thymus, ikba expression is higher in the cortex than in the medulla (Weih et al., 1994).

In conclusion, both avian and murine c-Rel proteins might be indirectly involved in T-cell maturation via their expression in antigen-presenting cells, but this expression seems restricted to epithelial cells in mouse, whereas it also extends to dendritic cells and macrophages in chicken. In contrast, the sole avian cRel protein might be also involved in early lymphopoiesis via its expression in proliferating lymphocyte precursor cells.

\section{MATERIAL AND METHODS}

\section{Animals}

Fertilized White Leghorn chicken eggs were incubated at $39^{\circ} \mathrm{C}$ in a humidified chamber. The age of embryos is indicated as E1, E2,.., E1 corresponding to $24 \mathrm{hr}$ of incubation.

\section{Histological Sections}

Chick embryo thymuses at different developmental stages were dissected in PBS and fixed at $4^{\circ} \mathrm{C}$ for 18 $\mathrm{hr}$ in $4 \%$ paraformaldehyde in $\mathrm{PBS}\left(\mathrm{Na}_{2} \mathrm{HPO}_{4^{-}}\right.$ $\left.\mathrm{NaH}_{2} \mathrm{PO}_{4}, 0.1 \mathrm{M}, \mathrm{pH} 7.4\right)$, then dehydrated in ethanol 
and toluene, embedded in paraffin, and processed for $5-6-\mu \mathrm{m}$ histological sections.

\section{Isolation and Primary Culture of Macrophages and Dendritic Cells}

The protocol was adapted from Oliver and Le Douarin (1984). E19 thymuses were dissected, minced with scissors, and crushed through a fine nylon gauze, which retains connective tissue and epithelial cells. The collected cell suspension was rinsed in culture medium (RPMI 1640, 10\% FCS, $1000 \mathrm{IU} / \mathrm{ml}$ penicillin, $1000 \mu \mathrm{g} / \mathrm{ml}$ streptomycin) and resuspended in 10\% BSA (Sigma) in RPMI 1640 buffered with Hepes $\mathrm{pH}$ 7.3. A discontinuous gradient of $22 \%, 27 \%$, and $29 \%$ BSA in RPMI 1640, pH 7.3, was prepared in a $5-\mathrm{ml}$ polyallomer tube and the cell suspension was layered on top of the gradient. After centrifugation at $35,000 \mathrm{~g}$ for $30 \mathrm{~min}$, the fraction located above the $22 \%$ layer was collected. Cells enriched in macrophages and dendritic cells were rinsed in culture medium and plated on glass coverslips for $4 \mathrm{hr}$ at $37^{\circ} \mathrm{C}$ in $5 \% \mathrm{CO}_{2}$ humidified incubator. Contaminating thymocytes were eliminated by hard pipetting. Adherent cells were fixed in $4 \%$ paraformaldehyde in PBS overnight at $4{ }^{\circ} \mathrm{C}$ and processed for in situ hybridization or immunocytochemistry.

\section{In Situ Hybridization}

\section{Synthesis of ${ }^{35} \mathrm{~S}$ RNA Probes}

The chicken full-length c-rel c-DNA was cloned in Bluescript SK- (Stratagene) (Abbadie et al., 1993). A 0.9-kb EcoRI fragment from the chicken $i k b a$ cDNA, kindly provided by $\mathrm{H}$. Bose, was cloned in Bluescript $\mathrm{SK}^{-}$phagemid (Stratagene). ${ }^{35} \mathrm{~S}$ RNA probes were transcribed from $2 \mu \mathrm{g}$ of linearized plasmids by $20 \mathrm{U}$ of either T7, T3, or SP6 RNA polymerase for sense and antisense probes in a $20-\mu$ l reaction mixture containing $200 \mu \mathrm{Ci}{ }^{35} \mathrm{~S}-\mathrm{CTP}(1300 \mathrm{Ci} / \mathrm{mMol}), 200$ $\mu \mathrm{M}$ UTP, ATP, and GTP for $1 \mathrm{hr}$ at $39^{\circ} \mathrm{C}$. To facilitate their penetration into cells, probes were submitted to a limited alkaline hydrolysis generating fragments of approximately 150 bases as recommended by (Cox et al., 1984).

\section{In Situ Hybridization}

In situ hybridization was adapted from the method of Cox et al., (1984), as described by Quéva et al. (1992). Briefly, after being deparaffinized and rehydrated, sections were incubated in $0.1 \mathrm{M}$ glycine, 0.2 $\mathrm{M}$ Tris- $\mathrm{HCl}, \mathrm{pH} 7.4$, for $10 \mathrm{~min}$ at $20^{\circ} \mathrm{C}$, treated with $1 \mu \mathrm{g} / \mathrm{ml}$ proteinase $\mathrm{K}$ (Boehringer Mannheim) for 15 $\min$ at $37^{\circ} \mathrm{C}$, postfixed in $4 \%$ paraformaldehyde, washed in PBS, acetylated 10 min with $0.25 \%$ acetic anhydride in $0.1 \mathrm{M}$ triethanolamine, washed in $2 \mathrm{X}$ SSC (0.3 M NaCl, $30 \mathrm{mM}$ sodium citrate), and dehydrated in ethanol. ${ }^{35} \mathrm{~S}$ RNA probes were denatured at $80^{\circ} \mathrm{C}$ and diluted in the hybridization buffer at a concentration of $50 \mathrm{pg} / \mu \mathrm{l}$. Hybridization was performed at $60^{\circ} \mathrm{C}$ for $18 \mathrm{hr}$. After a wash in $4 \mathrm{X}$ $\mathrm{SSC}$ at $20^{\circ} \mathrm{C}$, slides were treated with $10 \mu \mathrm{g} / \mathrm{ml}$ of RNase A (type III A, Sigma) for $30 \mathrm{~min}$ at $37^{\circ} \mathrm{C}$, subsequently washed in $0.1 \mathrm{X} \mathrm{SSC}$ at $60^{\circ} \mathrm{C}$, dehydrated by ethanol, and dipped in nuclear track emulsion (Kodak NTB2). The sections were exposed at $4^{\circ} \mathrm{C}$ for 2 weeks. After developing, sections were stained with a DNA intercalating fluorescent dye (Hoechst 33258), and mounted and observed under dark-field and UV illumination. Both antisense and sense probes were used, and the sense probes never gave any signal.

\section{Immunocytochemistry and Western Blot}

\section{Antibodies}

A rabbit immuno-purified anti-c-Rel serum (SB146) raised against the 15 carboxy terminal amino acids specific of the chicken c-Rel protein (Abbadie et al., 1993) was used both in Western blot and immunocytochemistry experiments. A normal rabbit immunoglobulin fraction (Dako) was used as negative control. A rabbit polyclonal anti-keratine serum (Dako) was used in immunocytochemistry to identify epithelial cells. Mouse monoclonal anti-chicken-CD3,-CD4, 
and -CD8 antibodies (Southern Biotechnology Associates) were used in immunocytochemistry to identify the different types of thymocytes.

\section{Immunocytochemistry}

After being deparaffinized and rehydrated, sections were incubated in $0.5 \mathrm{mg} / \mathrm{ml}$ Saponine (Sigma) in PBS for $30 \mathrm{~min}$; then endogenous peroxidase activity was quenched by incubation in $80 \%$ methanol, $20 \%$ PBS, $0.6 \% \mathrm{H}_{2} \mathrm{O}_{2}$ for $30 \mathrm{~min}$ followed by $30 \mathrm{~min}$ saturation in 5\% dry defatted milk in PBS. Sections were incubated with the primary antibody overnight at $4^{\circ} \mathrm{C}$. After three washes in PBS, the EXTRA-3 kit (Sigma Immunochemicals) and the AEC substrate system (Dako) were used to detect the primary antibody. Sections were counterstained with hematoxylin (Sigma) and mounted in Glycergel (Dako).

\section{Western Blot of Hematopoietic Organs}

Hematopoietic organs at various developmental stages were dissected in PBS, transferred into a solution containing $0.06 \mathrm{M}$ tris- $\mathrm{HCl}, \mathrm{pH} 6.8,5 \% \beta$ mercaptoethanol, $2 \%$. SDS, $10 \%$ glycerol, $0.002 \%$ bromophenol blue, homogenized in a Dounce, sonicated and centrifuged at $10,000 \mathrm{~g}$. In order to measure protein concentration in each sample, $20-\mu$ l aliquots were separated on a $10 \%$ SDS-PAGE; proteins were then stained with Coomassie-blue and the gel scanned lane by lane. Equicharged 10\% SDS-PAGE were run and transferred onto nitrocellulose sheets. Blots were first incubated 30 min with 5\% dry defatted milk in PBS, then $2 \mathrm{hr}$ at room temperature with SB146. After three washes in PBS, the sheets were incubated with horseradish-peroxidase-conjugated swine anti-rabbit immunoglobulin (Dako) for $2 \mathrm{hr}$ at room temperature. After washing, the peroxidase activity was revealed by incubation in diaminobenzidine $(30 \mathrm{mg}$ in $100 \mathrm{ml}$ $0.05 \mathrm{M}$ tris- $\mathrm{HCl}, \mathrm{pH} 7.4,0.01 \% \mathrm{H}_{2} \mathrm{O}_{2}$ ).

\section{Panoptic Coloration of Pappenheim}

This protocol of hematological coloration is described in Gabe (1968). Briefly, after being deparaffinized and rehydrated, sections were stained 3 min in MayGrünwald, $3 \mathrm{~min}$ in May-Grünwald/Sörensen buffer $\left(\mathrm{Na}_{2} \mathrm{HPO}_{4}-\mathrm{KH}_{2} \mathrm{PO}_{4}, 0.1 \mathrm{M}, \mathrm{pH}\right.$ 6.8) $\mathrm{V} / \mathrm{V}$, washed in Sörensen buffer, stained in Giemsa/Sörensen buffer $1 \mathrm{~V} / 75 \mathrm{~V}$ for $15 \mathrm{~min}$, washed in Sörensen buffer, differentiated in $0.15 \%$ acetic acid, washed in Sörensen buffer, and dehydrated in two washes of acetone and one wash of toluene. Sections were then mounted in Eukitt (O. Kindler GmbH, Germany).

\section{Acknowledgements}

We are grateful to Eric Maire and Virginie Mattot for their technical help and advice. We thank Jean Coll, Pierre-Antoine Desfossez, Véronique Fafeur, Corine Glineur, and Fabrice Soncin for critical reading of the manuscript. This work was supported by grants from the Institut Pasteur de Lille, the Centre National de la Recherche Scientifique, and the Association pour la Recherche sur le Cancer. C.H. was supported by a training grant from the Association pour la Recherche sur le Cancer.

\section{References}

Abbadie C., Kabrun N., Bouali F., Smardova J., Stéhelin D., Vandenbunder B. and Enrietto P. (1993). High levels of c-rel expression are associated with programmed cell death in the developing avian embryo and in bone marrow cells in vitro. Cell 75: 899-912.

Barth C.F., Ewert D.L., Olson W.C. and Humphries E.H. (1990). Reticuloendotheliosis virus REV-T (REV-A)-induced neoplasia: Development of tumors within the T-lymphoid and myeloid lineages. J. Virol. 64: 6054-6062.

Bauerle P.A. and Henkel T. (1994). Function and activation of NF$\kappa \mathrm{B}$ in the immune systeme. Annu. Rev. Immunol. 12: 141-179.

Boehmelt G., Madruga J., Dörfler P., Briegel K., Schwarz H., Enrietto P.J., and Zenke M. (1995). Dendritic cell progenitor is transformed by a conditional v-Rel Estrogen Receptor fusion protein v-RelER. Cell 80: 341-352.

Boyd R.L., Wilson T.J., Bean A.G. and Ward H.A. (1992). Phenotypic characterization of chicken thymic stromal elements. Dev. Immunol. 2: 51-66.

Carrasco D., Weih F. and Bravo R. (1994). Developmental expression of the mouse c-rel proto-oncogene in hematopoietic organs. Development 120: 2991-3004.

Coltey M., Jotereau F.V. and Le Douarin N.M. (1987). Evidence for a cyclic renewal of lymphocyte precursor cells in the embryonic chick thymus. Cell Diff. 22: 71-82.

Cox K.H., DeLeon D.V., Angerer L.M. and Angerer R.C. (1984). Detection of mRNAs in sea urchin embryos by in situ 
hybridization using asymmetric RNA probes. Dev. Biol. 101: 485-502.

Davis J.N., Bargmann W. and Bose H.J. (1990). Identification of protein complexes containing the c-rel proto-oncogene product in avian hematopoietic cells. Oncogene 5: 1109-1115.

Dieterlen-Lièvre F. (1994). Hemopoiesis during avian Ontogeny. Poultry Sci. Rev. 5: 273-305.

Duncan R.L. and McArthur W.P. (1978). Partial characterisation and the distribution of chicken mononuclear cells bearing the $\mathrm{Fc}$ receptor. J. Immunol. 120: 1014-1020.

Gabe M. (1968). Techniques Histologiques (Paris: Masson et Cie).

Guillemot F.P., Oliver P.D., Peault B.M. and Le Douarin N. (1984). Cells expressing Ia antigens in the avian thymus. J. Exp. Med. 160: $1803-1819$

Houldsworth J., Mathew S., Rao P.H., Dyomina K., Louie C.D., Parsa N., Offit K. and Chaganti R.S.K. (1996). REL protooncogene is frequently amplified in extranodal diffuse large cell lymphoma. Blood 87: 25-29.

Hrdlickova R., Nehyba J. and Humphries E.H. (1994). v-rel induces expression of three avian immunoregulatory surface receptors more efficiently than c-rel. J. Virol. 68: 308-319.

Hrdlickova R., Nehyba J., Roy A., Humphries E.H. and Bose H.R., Jr. (1995). The relocalization of v-rel from the nucleus to the cytoplasm coincides with induction of expression of Ikba and nfkbl and stabilization of $\mathrm{I} \kappa \mathrm{B}-\alpha$. J. Virol. 69: 403-413.

Huguet C., Enrietto P., Vandenbunder B. and Abbadie C. (1994). C-Rel: A multifunctional transcription factor? Cell Death Diff. 1: $71-76$

Joos S., Otano-Joos M.I., Ziegler S., Brüderlein S., du Manoir S., Bentz M., Möller P. and Lichter P. (1996). Primary mediastinal (thymic) B-cell lymphoma is characterized by gains of chromosomal material including 9p and amplification of the REL gene. Blood 87: 1571-1578.

Jotereau F.V. and Le Douarin N.M. (1982). Demonstration of a cyclic renewal of the lymphocyte precursor cells in the quail thymus during embryonic and perinatal life. J. Immunol. 129: 1869-1877.

Kerr L.D., Inoue J., Davis N., Link E., Baeuerle P.A., Bose H.J. and Verma I.M. (1991). The rel-associated pp40 protein prevents DNA binding of Rel and NF-kappa B: Relationship with I kappa B beta and regulation by phosphorylation. Genes Dev. 5: 1464-1476.

Kochel T., Mushinski J.F. and Rice N.R. (1991). The $v$-Rel and $c$ $R e l$ proteins exist in high molecular weight complexes in avian and murine cells. Oncogene 6: 615-626.

Köntgen F., Grumont R.J., Strasser A., Metcalf D., Li R., Tarlinton D. and Gerondakis S. (1995). Mice lacking the c-rel protooncogene exhibit defects in lymphocyte proliferation, humoral immunity, and interleukin-2 expression. Genes Dev. 9: 1965-1977.

Kopp E.B. and Ghosh S. (1995). NF- $\kappa$ B and Rel proteins in innate immunity. Adv. Immunol. 58: 1-27.

Kralova J., Schatzle J.D., Bargmann W. and Bose H.R.J. (1994). Transformation of avian fibroblasts overexpressing the c-rel proto-oncogene and a variant of c-rel lacking $40 \mathrm{C}$-terminal amino acids. J. Virol. 68: 2073-2083.

Le Douarin N.M. and Jotereau F.V. (1975). Tracing of cells of the avian thymus through embryonic life in interspecific chimeras. J. Exp. Med. 142: 17-40.
Lewis R.B., McClure J., Rup B., Niesel D.W., Garry R.F., Hoelzer J.D., Nazerian K.A. and Bose H.R. (1981). Avian reticuloendotheliosis virus: Identification of the hematopoietic target cell for transformation. Cell 25: 421-431.

Lu D., Thompson J.D., Gorski G.K., Rice N.R., Mayer M.G. and Yunis J.J. (1991). Alterations at the rel locus in human lymphoma. Oncogene 6: 1235-1241.

Miyamoto S., Chiao P.J. and Verma I.V. (1994). Enhanced IkBa degradation is responsible for constitutive NF-kB activity in mature murine B-cell lines. Mol. Cell. Biol. 14: 3276-3282.

Miyamoto S. and Verma I.M. (1995). Rel/NF- $\kappa \mathrm{B} / \mathrm{I} \kappa \mathrm{B}$ story. Adv. Cancer Res. 66: 255-292.

Moore B.E. and Bose H.R. (1989). Expression of the c-rel and cmyc proto-oncogenes in avian tissues. Oncogene 4: 845-852.

Morrison L.E., Boehmelt G., Beug H. and Enrietto P.J. (1991). Expression of $v$-rel in a replication competent virus: Transformation and biochemical characterization. Oncogene 6: 1657-1666.

Morrison L.E., Kabrun N., Mudri S., Hayman M.J. and Enrietto P.J. (1989). Viral $\mathrm{rel}$ and cellular $\mathrm{rel}$ associate with cellular proteins in transformed and normal cells. Oncogene 4: 677-683.

Nossal G.J.V. (1994). Negative selection of lymphocytes. Cell 76: 229-239.

Oliver P. and Le Douarin N.M. (1984). Avian thymic accessory cells. J. Immunol. 132: 1748-1755.

Olson L.D. (1967). Histopathologic and hematologic changes in moribund stages of chicks infected with T-virus. Am. J. Vet. Res. 28: 1501-1507.

Peck R., Murthy K.K. and Vainio O. (1982). Expression of B-L (Ialike) antigens on macrophages from chicken lymphoid organs. J. Immunol. 129: 4-5.

Phi Van L. (1996). Transcriptional activation of the chicken lysozyme gene by NF- $\kappa$ Bp65 (RelA) and c-Rel, but not by NF$\kappa$ Bp50. Biochem J. 313: 39-44.

Quéva C., Ness S.A., Graf T., Vandenbunder B. and Stéhelin D. (1992). Expression patterns of $c-m y b$ and of $v-m y b$ induced myeloid-1 (mim-1) gene during the development of the chick embryo. Development 114: 125-133.

Schatzle J.D., Kralova J. and Bose H.R. (1995). Avian $\mathrm{I} \kappa \mathrm{B} \alpha$ is transcriptionally induced by $\mathrm{c}-\mathrm{Rel}$ and $\mathrm{v}$-Rel with different kinetics. J. Virol. 69: 5383-5390.

Sevoian M., Larose R.N. and Chamberlain D.M. (1964). Avian lymphomatosis. VI. A virus of unusual potency and pathogenicity. Avian Dis. 8: $336-347$.

Simek S. and Rice N.R. (1988). Detection and characterization of the protein encoded by the chicken c-rel protooncogene. Oncogene Res. 2: 103-119.

Verma I.M., Stevenson J.K., Schwarz E.M., Van Antwerp D. and Miyamoto S. (1995). Rel/NF- $\kappa \mathrm{B} / \mathrm{I} \kappa \mathrm{B}$ family: Intimate tales of association and dissociation. Genes Dev. 9: 2723-2735.

von Boehmer H. (1994). Positive selection of lymphocytes. Cell 76: 219-228.

Weih F., Carrasco D. and Bravo R. (1994). Constitutive and inducible Rel/NF- $\kappa \mathrm{B}$ activities in mouse thymus and spleen. Oncogene 9: 3289-3297.

Zhang J.Y., Olson W., Ewert D., Bargmann W. and Bose H.J. (1991). The v-rel oncogene of avian reticuloendotheliosis virus transforms immature and mature lymphoid cells of the B cell lineage in vitro. Virology 183: 457-466. 


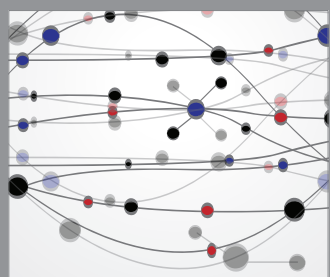

The Scientific World Journal
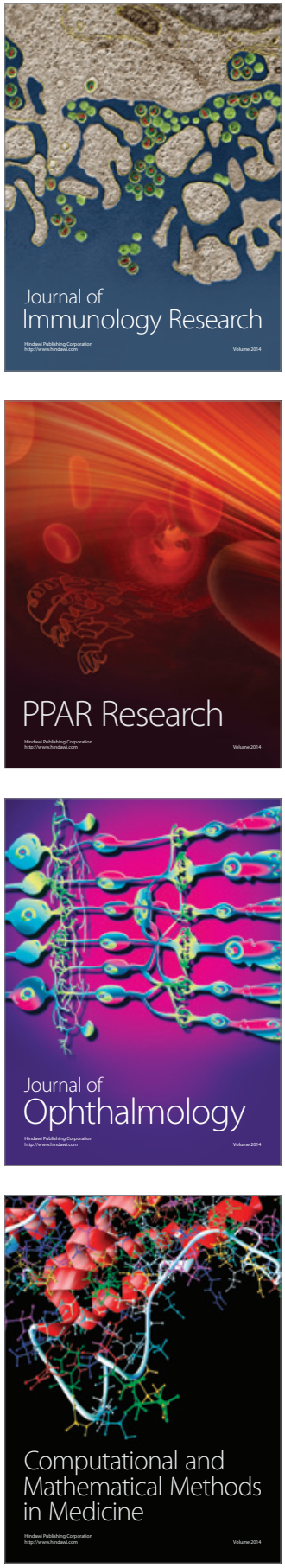

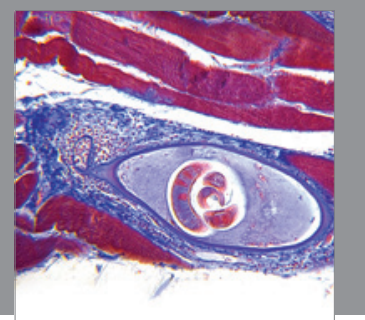

Gastroenterology

Research and Practice
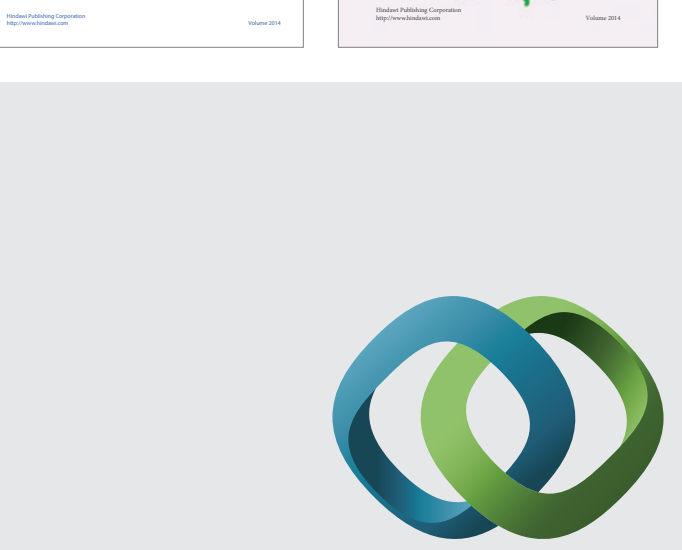

\section{Hindawi}

Submit your manuscripts at

http://www.hindawi.com
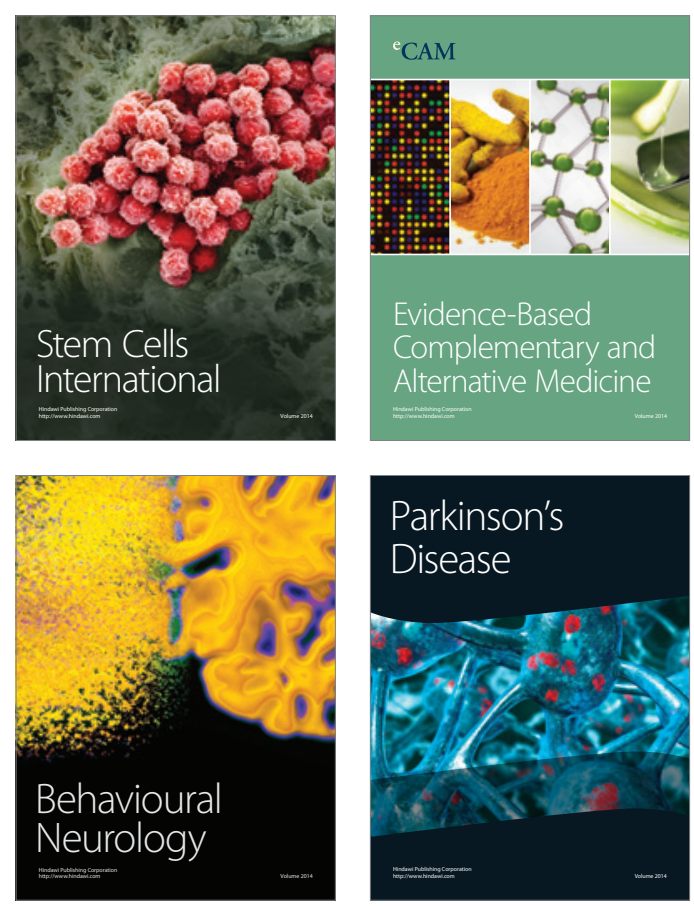

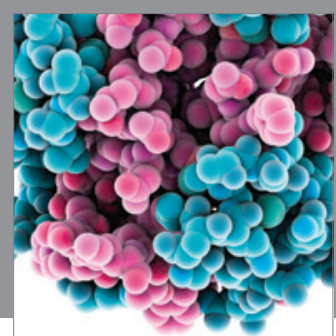

Journal of
Diabetes Research

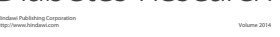

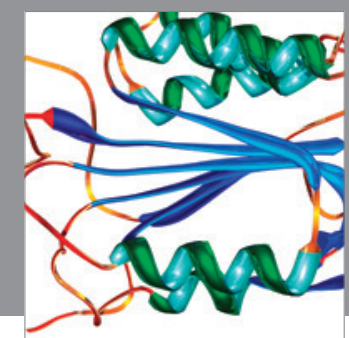

Disease Markers
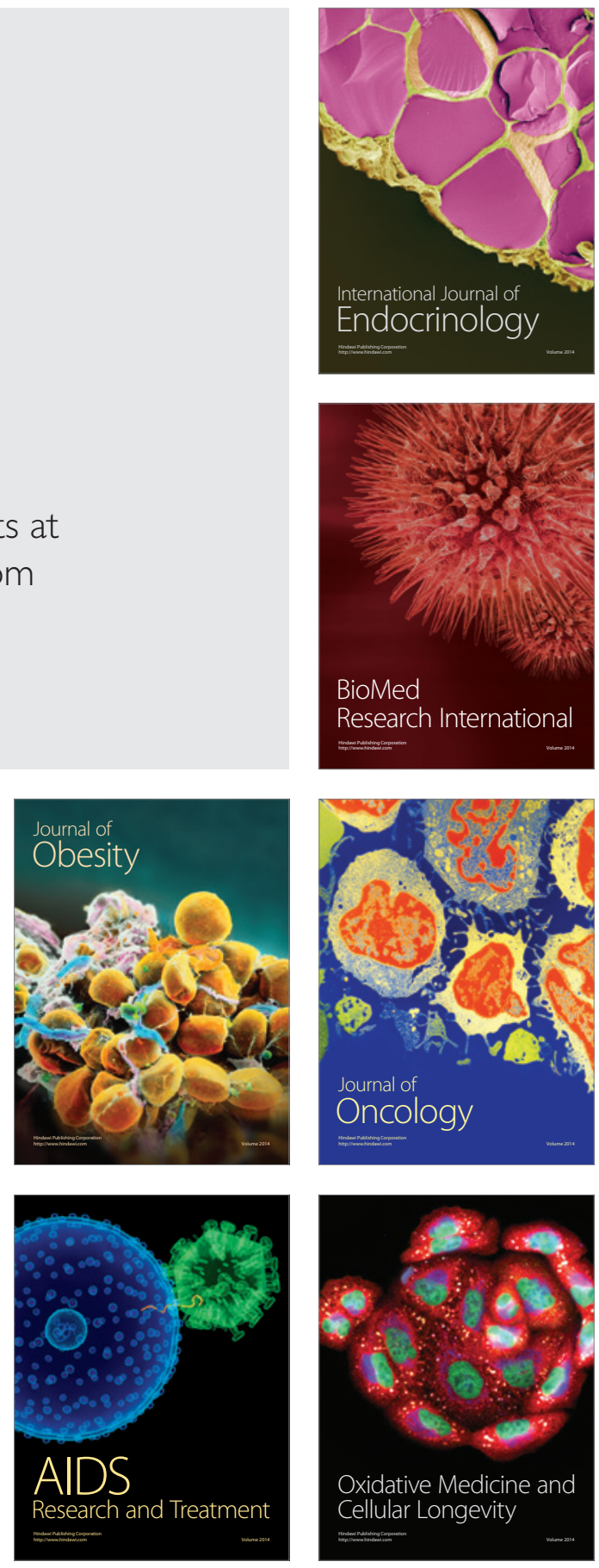